\title{
Tatiana Majcherkiewicz
}

ORCID: 0000-0002-8064-9699

Uniwersytet Pedagogiczny im. Komisji Edukacji Narodowej w Krakowie

\section{Funkcjonowanie systemu wielopoziomowego w Polsce na przykładzie relacji między poziomem wojewódzkim a lokalnym*}

https://doi.org/10.19195/1643-0328.28.2

Słowa kluczowe: system wielopoziomowy, marszałkowie województw, koalicje, samorząd lokalny i województw

\section{Wprowadzenie teoretyczne}

W badaniach nad współczesnymi demokratycznymi państwami Europy Zachodniej, szczególnie w analizach politologicznych koncentrujących się na regionach, coraz częściej stosowana jest perspektywa rządzenia wielopoziomowego (multi-level governance, MLG). Perspektywa ta zwraca uwagę na zmiany struktur współczesnych państw pod wpływem zjawisk takich, jak z jednej strony europeizacja, a $\mathrm{z}$ drugiej regionalizacja, dewolucja i federalizacja. Odrzuca się założenie metodologicznego centralizmu, które mówi, że głównym obszarem zainteresowań powinna być polityka ogólnokrajowa ${ }^{1}$. Decentralizacja i powstanie instytucji przedstawicielskich na "szczeblu” regionalnym, a zarazem profesjonalizacja polityki regionalnej (pozycje regionalnych parlamentarzystów i ministrów są zajmowane przez zawodowych polityków) powodują, że ważnym obszarem badań stają się regionalne procesy polityczne. Dynamicznie rozwija się nurt badań nad koalicjami regionalnymi, podejmowane są także analizy karier polityków regionalnych ${ }^{2}$. W przypadku Polski za stanowiska zajmowane przez profesjonalnych po-

\footnotetext{
* Opracowanie to jest częścią projektu badawczego zatytułowanego: Rekrutacja i skład społeczno-demograficzny regionalnych elit samorzadowych w latach 1998-2014; badanie dofinansowane jest przez Narodowe Centrum Nauki (nr projektu 2013/11/B/HS6/01196).

${ }^{1}$ C. Jeffery, Multi-Level Party Competition in Federal and Regional States, [w:] Handbook on Multi-Level Governance, red. H. Enderlein, S. Wälti, M. Zürn, Cheltenham 2011, s. 136-152.

${ }^{2} \mathrm{~K}$. Deschouwer, Multilevel systems and political careers: the pleasures of getting lost, ECPR Joint Sessions of Workshops, Grenoble, 6-11 kwietnia 2001, https://ecpr.eu/Filestore/PaperProposal/a06d1462-
} 
lityków uznać można pozycje marszałków województw i w przeważającej mierze także osób zasiadających w zarządach województw ${ }^{3}$.

Równocześnie perspektywa MLG zakłada, że polityki regionalnej nie można zrozumieć w izolacji od wpływu innych „szczebli”: centralnego, lokalnego, a także europejskiego. W Polsce marszałkowie województw wskazywali na przykład, że ich pozycja polityczna uległa znaczącemu wzmocnieniu po wejściu do Unii Europejskiej. Założyć można, że reforma administracyjna wprowadzona w 1999 roku to początek kształtowania się systemu wielopoziomowego w Polsce, choć w pełni ukształtowany został on dopiero po wstąpieniu do UE. Decydujące znaczenie miał dostęp do funduszy europejskich.

Zakłada się, że prowadzenie skutecznej polityki w systemie wielopoziomowym wymaga jej koordynacji. Niespójna polityka koalicyjna może nie być zrozumiała ani dla potencjalnych wyborców, ani dla członków partii ${ }^{4}$.

Rządzenie wielopoziomowe wyodrębnia trzy główne rodzaje koalicji. Koalicja przystająca tworzona jest przez te same partie na „szczeblu” centralnym i regionalnym, dzięki temu nie przecina ona zasadniczej linii ogólnokrajowego podziału na rząd i opozycję. Tego kluczowego podziału politycznego nie narusza również koalicja w pełni nieprzystająca. Na gruncie polskim za tego typu porozumienie można uznać koalicję SLD-PSL na początku pierwszej kadencji samorządu województw w czasie, kiedy Jerzy Buzek stał na czele rządu koalicyjnego AWS-UW. W tym samym okresie w województwie podkarpackim AWS tworzyła „jednopartyjny” zarząd województwa, a w województwie opolskim powstało porozumienie AWS-UW-MN. Obydwa te przypadki można zaklasyfikować jako koalicje częściowo przystające. Skład polityczny zarządów w tych dwu województwach uświadamia, że w wielu regionach odtworzenie koalicji w pełni przystających utrudniają między innymi różnice $\mathrm{w}$ wynikach wyborów. W związku z tym można zauważyć, że najczęściej tworzone są koalicje częściowo przystające. Natomiast według założeń MLG politycy będą dążyć do unikania koalicji krzyżujących, czyli tych przecinających podział ogólnokrajowy ${ }^{5}$. Przy tym założeniu bardziej pożądanym partnerem koalicyjnym w województwie śląskim, który powinien być uwzględniony w związku z koniecznością rozszerzenia koalicji PO-PSL po wyborach w 2014 roku, powinien być

2ca4-49e9-8f93-dc5198ba515e.pdf (dostęp: 20.03.2020); J. Borchert, K. Stolz, Introduction: Political careers in multi-level systems, „Regional \& Federal Studies” 21, 2011, nr 2, s. 107-115; J. Botella et al., A new political elite in Western Europe? The political careers of regional prime ministers in newly decentralised countries, „French Politics” 8, 2010, nr 1, s. 42-61.

${ }^{3}$ Za zawodowych polityków uznać można ponad 90\% marszałków, ale tylko $2 / 3$ osób zasiadających w zarządach województw - T. Majcherkiewicz, Marszałkowie województw jako politycy regionalni i reprezentanci społeczności regionalnych, „Studia Humanistyczne AGH” 3, 2017, nr 16, s. 79-103.

${ }^{4}$ I. Ştefuriuc, Government Formation in Multi-Level Settings: Party Strategy and Institutional Constraints, Basingstoke 2013, s. 22.

${ }^{5}$ Ibidem, s. 89-152; K. Deschouwer, Formation and congruence in a multi-layered setting: Belgium 1995-2008, „Regional \& Federal Studies” 19, 2009, nr 1, s. 16; E. Linhart, Coalition building on the federal and on the länder level in Germany, IPSA World Congress of Political Science, Poznań, 23-28 lipca 2016, s. 1-15. W literaturze polskiej omówienie teorii wzorów tworzenia koalicji w ramach perspektywy MLG w: T. Majcherkiewicz, Koalicje regionalne w perspektywie rzadzenia wielopoziomowego, „Studia Polityczne” 4, 2017, nr 45, s. 33-56. 
RAŚ, a nie SLD (choć MLG dostrzega też większe prawdopodobieństwo odtworzenia dotychczasowej koalicji, czyli takiej, która istniała w momencie podejmowania decyzji).

\section{Relacje między poziomem wojewódzkim a lokalnym w opinii marszałków województw}

Celem artykułu jest przedstawienie opinii marszałków na temat kształtowania się relacji między poziomem wojewódzkim a lokalnym. Przy rekonstrukcji wizji wspomnianych relacji zwrócono uwagę na to, jak zmienia się ona w czasie i czy była ona zróżnicowana zależnie od przynależności politycznej. Podstawą analiz przedstawionych w tym artykule stały się wywiady swobodne przeprowadzone $\mathrm{z}$ marszałkami województw od pierwszej do piątej kadencji (wybranych na ten urząd do końca 2014 roku) ${ }^{6}$. Wywiady te uzupełnione zostały o informacje zamieszczone w lokalnej prasie, między innymi dotyczące przebiegu sesji sejmiku, oraz wywiadami z członkami elity regionalnej (osobami zasiadającymi w zarządach województw).

Opisując wzajemne relacje między samorządem wojewódzkim a regionalnym, przedstawiciele elit regionalnych dostrzegali ich dwie zasadnicze formy:

- W przypadku wielu województw na pierwszy plan wysuwana była relacja między samorządem wojewódzkim a jego głównymi miastami, szczególnie obecnymi stolicami województw. W opisach relacji z samorządem gminnym dodatkowo zwracano uwagę na szersze procesy polityczne, zmianę układu sił między poziomem regionalnym a lokalnym w konsekwencji wejścia do UE oraz dostępu do funduszy europejskich. Procesy te wzmacniały potrzebę prowadzenia polityki wielopoziomowej.

- W innych regionach jedną z najważniejszych relacji tego typu było uzgadnianie kompozycji politycznej koalicji powiatowych. Podejmowanie tego typu działań lub powstrzymywanie się od nich skłaniało marszałków do przedstawienia bardziej ogólnych opinii i ocen dotyczących prowadzenia polityki koalicyjnej uwzględniającej uwarunkowania związane z wielopoziomowością struktur współczesnego państwa. Kwestia przystawalności koalicji, w ich opinii, była ściśle powiązana z pytaniem o rolę partii ogólnokrajowych w samorządzie lokalnym. W rozważaniach tych odwoływano się do

${ }^{6}$ Zgodnie ze standardami w tego typu badaniach respondenci poinformowani zostali, iż zachowana zostanie anonimowość ich wypowiedzi. Ze względu na to, że w niektórych wypowiedziach poruszane były wrażliwe kwestie, jeżeli było to konieczne, w cytatach pominięto szczegóły umożliwiające identyfikację rozmówcy. W badaniu udział wzięli (w porządku alfabetycznym): M. Baszko, A. Bocheński, A. Bratkowski, G. Brzezin, A. Buła, P. Całbecki, Z. Cholewiński, M. Czarski, B. Dębski (marszałek elekt), J. Dworzański, J. Faliński, W. Fisiak, R. Galla, O. Geblewicz, H. Gołębiewski, K. Grabczuk, K. Hetman, M. Jabłoński, A. Jarubas, R. Jurkowlaniec, M. Karapyta, J. Kozłowski, J. Krzyżewski, M. Łapiński, A. Łoś, H. Makarewicz, W. Matusewicz, A. Matusiewicz, S. Mikołajczak, J. Moszyński, Z. Meyer, N. Obrycki, J. Olbrycht, W. Ortyl, D. Piotkowski, E. Polak, J. Protas, A. Ryński, B. Rzońca, W. Saługa, J. Schabieński (osoba pełniąca funkcje organów samorządu województwa podlaskiego), J. Sepioł, S. Sosnowski, E. Stańczyszyn, M. Struk, A. Struzik, J. Szczepańczyk, J. Szmit, K. Szymański, B. Śmigielski, M. Teodorczyk, J. Waszkiewicz, S. Witaszczyk, F. Wołodźko, M. Woźniak, P. Wróblewski, J. Zarębski, S. Zgrzywa, Z. Zychowicz. 
dwóch głównych, ale odmiennych argumentów: z jednej strony do zaufania do partii politycznej, prowadzącej spójną politykę na różnych poziomach, z drugiej natomiast do demokracji lokalnej i niezależności struktur samorządowych.

\section{System wielopoziomowy: relacje między samorządem wojewódzkim a głównymi miastami regionu}

Jednym z najbardziej wyrazistych przykładów bezpośredniego oddziaływania dużych miast na poziom województw jest przypadek zmiany koalicji rządzącej w Olsztynie (z koalicji UW-AWS na UW-SLD) i następującej po kilku miesiącach po niej przebudowy koalicji kierującej województwem warmińsko-mazurskim (z AWS-UW-PSL na SLD-UW-PSL). Wydarzenia te zostały szeroko nagłośnione w lokalnej prasie i opisane $\mathrm{w}$ literaturze przedmiotu, dlatego $\mathrm{w}$ artykule tym podano nazwę miasta ${ }^{7}$. Interesująca jest również zmiana koalicji rządzącej województwem w 1999 roku. Ukazuje ona nie tylko wpływ samorządu lokalnego, ale też złożoność wzajemnych relacji - ich wielopoziomowość. Przy opisie zachodzących wówczas wydarzeń dostrzegano również wpływ „szczebla” centralnego. Jeden z marszałków, uczestniczący w tych wydarzeniach, tak opisywał wielopoziomowość tych oddziaływań:

T.M.: Z jednej strony PSL wychodzi z koalicji rządzącej województwem, ale Unia Wolności trwa, czy to ze względu na te powiązania...?

— Rada Miasta Olsztyna i relacje rządowe, myślę, że to było decydujące wówczas. [...] przede wszystkim może powiązania rządowe, bo to było decydujące, wtedy jeszcze ta koalicja była tam na szczeblu rządowym.

W perspektywie wielopoziomowej wydarzenia te, rozgrywające się na trzech poziomach: lokalnym, regionalnym i centralnym, postrzegał również inny marszałek województwa warmińsko-mazurskiego. Oddziaływanie polityki ogólnokrajowej tłumaczyło odmienny stosunek do pozostawania w koalicji z AWS partnerów koalicyjnych: PSL i UW. Zachowanie UW, która przez dłuższy czas, pomimo wyjścia PSL z koalicji, dążyła do jej utrzymania, wynikało przede wszystkim z tego, że: „oni są w koalicji z AWS-em na szczeblu krajowym, rządowym"8. Te uwarunkowania spowodowały, że UW prawie przez pół roku trwała w mniejszościowej koalicji. Rozpatrując wielopoziomowość relacji w kontekście zmiany koalicji rządzącej województwem warmińsko-mazurskim, podejście „pionowe” można wzbogacić o wymiar poziomy. Odwołanie marszałka z AWS pociągało za sobą rezygnację wicewojewody reprezentującego UW.

Ukazująca oddziaływanie wielopoziomowe zmiana koalicji rządzącej województwem warmińsko-mazurskim została szeroko opisana. Wywiady z marszałkami sugerują, że nie była to jedyna taka sytuacja. Marszałek trzeciej kadencji twierdził, że inna konkurująca partia próbowała zmienić koalicję rządzącą województwem, korzystając

7 T. Gajowniczek, Bastion lewicy zdobyty. Wybory samorządowe w województwie warmińsko-mazurskim, [w:] R. Alberski, M. Cichosz, Ł. Tomczak, Wybory do sejmików województw w 2006 roku, Wrocław 2010, s. 221.

8 P. Pietkun, Sejmik wzięty, „Gazeta w Elblągu” 9 października 1999, s. 1. 
z zasobów dostępnych na „szczeblu” lokalnym. Podczas spotkania prezydenta miasta X. i szefa regionalnych struktur partii P. z radnymi sejmiku zasugerowano życzliwość: gdyby któryś z nich „miał problemy z pracą czy z czymś takim, to proszę”. Prezydent, formalnie bezpartyjny, sympatyzujący jednak z partią P., wspierał ją w próbie przejęcia przez nią władzy na „szczeblu” regionalnym. Marszałek ten dostrzegł też wymianę zasobów w drugą stronę - korzyści z tego typu relacji dla prezydenta miasta. Pomimo że w wyborach na prezydentów miast wyborcy preferowali kandydatów bezpartyjnych i jako taki przedstawiał się prezydent stolicy regionu, to w głosowaniu do rady miasta ci sami wyborcy głosowali na partie polityczne. To radni ugrupowania P., a nie radni jego lokalnego ugrupowania gwarantowali mu stabilną większość.

Odmienny od przedstawionego powyżej obraz zasugerował inny respondent, odwołując się do sytuacji politycznej w dużych miastach położonych na terenie aglomeracji śląskiej. W jego opinii wprowadzenie bezpośrednich wyborów na prezydentów miast w 2002 roku spowodowało, że interesy prezydentów miast i polityków regionalnych, będących politykami partyjnymi, były rozbieżne. Według tej interpretacji powstałe ramy instytucjonalne utrudniały lub uniemożliwiały współdziałanie w ramach systemu wielopoziomowego.

Miasta [...] na prawach powiatu - tam są wybory prezydentów bezpośrednie, przykładowo prezydent w takim mieście jak J. [nazwa miasta - T.M.] ma głęboko w poważaniu wszystkich radnych. On potrzebuje mieć zaplecze, ale nie polityczne zaplecze, tylko potrzebuje mieć radnych, którzy jego popierają, a nie reprezentują jakąś linię partii politycznej. Wręcz mu to przeszkadza, bo wtedy jest problem konfrontacji z partią polityczną, najbardziej z partią rządzącą. Gdyż na partię rządzącą można wszystkie swoje niepowodzenia zrzucić. Jak im się coś nie udaje albo nie mają pieniędzy, to jest rząd winny, bo im nie dał, bo im zabrał, bo tamto zrobił albo nie stworzył warunków prawnych, żeby rozwiązać problemy, które oni mają. [...] Kampanie wyborcze są prowadzone przeciwko komuś. Czyli trzeba tego złego napiętnować i bardzo często jest to marszałek, bo marszałek mi nie dał pieniędzy, bo marszałek mi drogi nie zrobił, albo czegoś tam...

W tym kontekście trzeba zwrócić uwagę, że w opisach oddziaływania samorządu lokalnego szczególne miejsce przypisywano w niektórych województwach ich obecnym stolicom - metropoliom. Do tej kategorii włączono przede wszystkim Wrocław, ale także Kraków, Poznań i Łódź.

Krytyka relacji między metropolią a regionem szczególnie wyraźnie słyszalna była w odniesieniu do Wrocławia. Jeden z marszałków argumentował, że choć integracja europejska stworzyła możliwość odgrywania nowej i ważnej roli na poziomie europejskim, to odbywało się to kosztem osłabienia regionu:

Nie ulegało dla nas wątpliwości, że podstawowa rola Wrocławia to bycie stolicą Dolnego Śląska. Oni sobie wyobrażają, że będą metropolią europejską - jakieś Światowe Dni Kultury i takie inne... Natomiast nie chcą odgrywać roli, do której miasto zostało stworzone: czyli bycia metropolią dla tego regionu, centrum intelektualnym i centrum rozwiązywania problemów regionalnych, tym oni absolutnie nie chcą być.

Stosunkowo często marszałkowie zwracali uwagę na głęboki konflikt strukturalny między prezydentami stolic województw a zarządem województwa. Podkreślano konkurencję ze strony stolic regionów, którą postrzegano jako destrukcyjną:

O dobre relacje trzeba zabiegać, ale samorządy lokalne nie odgrywają tutaj roli. Natomiast, jeśli idzie o relacje: metropolia a zarząd województwa, to jest kompletnie inna bajka. I to jest przede wszystkim model 
rywalizacji. I to nie ma znaczenia, kto politycznie rządzi. Jest po prostu strukturalny konflikt między szefem metropolii a szefem województwa. Dawniej to była pogarda ze strony szefa metropolii w stosunku do marszałka [...] Bo to w ogóle: „Kto to jest?”.

Teraz to się odwróciło, to jest zawiść prezydentów miast, że marszałkowie mają tak dużo pieniędzy i są panami życia i śmierci, jeśli idzie o polityczną przyszłość poszczególnych wójtów, burmistrzów i prezydentów, bo mogą dać na ich projekty pieniądze albo nie dać. Tak że wszystkie samorządy, z metropoliami włącznie, stały się klientami marszałka. To jest najbardziej fundamentalna zmiana, jaką przyniosło wstąpienie Polski do Unii Europejskiej. Kompletnie zmieniło relacje między polskimi samorządami. Dlatego jest głęboka rywalizacja i napięte stosunki.

Wpływ szczebla lokalnego wzrastał, gdy wśród niezadowolonych dominowali reprezentanci partii rządzącej województwem lub gdy większość liderów samorządu lokalnego w danym województwie odczuwała, że ich głos nie jest słyszalny; szczególnie gdy dotyczyło to dostępu do funduszy europejskich. Ilustruje to poniższa wypowiedź:

Na pewno jest ten wpływ. Trzeba się z tym wpływem liczyć. I rzeczywiście w tym konkretnym przypadku X. [nazwisko marszałka, jednego z jego poprzedników - T.M.] było tak, że wtedy, kiedy był odwoływany, te głosy były rzeczywiście mocno słyszalne, że miał taki bardzo autorski pomysł na Regionalny Program Operacyjny, i bardzo mocno go forsował, przy dosyć dużym oporze samorządowców z regionu.

$\mathrm{Na}$ koniec, odwołując się do wpływu „szczebla” europejskiego na tworzenie się systemu wielopoziomowego w samorządach, warto wskazać, że nie tylko wzmocniła się pozycja zarządu województwa, ale w rzeczywistości zmienił się kształt instytucjonalny samorządu w Polsce. Marszałek Janusz Sepioł uznaje, że relacja między samorządem województwa a lokalnym po 2004 roku przypomina model hierarchiczny ${ }^{9}$. Ograniczona zostaje samodzielność gmin i powiatów, co jest sprzeczne z wizją ich współdziałania sformułowaną przez twórców reformy samorządowej:

Brak zależności gmin od powiatów i województw był zresztą warunkiem, pod którym samorządy gminne zgodziły się na reformę regionalną. Jednak doktryna tej niezależności, czyli jak niektórzy mówią „równoległości” samorządów, została zasadniczo podważona po 2004 roku. Gdy województwa zaczęły dzielić środki europejkkie, gminy i powiaty stały się z natury rzeczy petentami regionów. To rozdział środków dokonywany przez województwa decyduje dziś o szansach rozwojowych, o być albo nie być poszczególnych jednostek ${ }^{10}$.

\section{Koalicje przystające na poziomie powiatowym i relacje wielopoziomowe między województwami i powiatami}

W odróżnieniu od powiązań między regionami a „szczeblem” centralnym marszałkowie zdecydowanie rzadziej dostrzegali funkcjonowanie systemu wielopoziomowego w relacji województwo-poziom lokalny. Wypowiedzi respondentów wskazują, że w kolejnych

9 Choć przypuszczać można, że ten układ sił ulegnie zmianie po 2020 roku — pozycja samorządów województw zostanie osłabiona w związku ze znacząco niższym poziomem środków przez nie redystrybuowanych (J. Bober et al., Narastające dysfunkcje, zasadnicze dylematy, konieczne działania. Raport o stanie samorządności terytorialnej w Polsce, Kraków 2013, s. 23).

10 J. Sepioł, Pejzaż dziesięciolecia, „Gazeta Wyborcza” (dodatek krakowski), 19 stycznia 2009, s. 9. 
kadencjach coraz częściej podejmowane były jednak próby działań strategicznych, koordynujących politykę między różnymi poziomami samorządu.

Dość popularna była opinia o odrębności poszczególnych poziomów i niemożności prowadzenia, choćby w ograniczonym zakresie, strategii wielopoziomowej. Odzwierciedla ją poniższy cytat:

Nie, nie, to takie rozszerzanie, naprawdę sejmik to jest zupełnie co innego. Powiat - tam są różne, czasami takie jakieś dziwne koalicje. Takie, co są na szczeblu krajowym niemożliwe, to na tym szczeblu lokalnym są możliwe, różne SLD z PiS-em.

Przedstawioną powyżej opinię warto skonfrontować z zamieszczonym poniżej głosem marszałka czwartej i piątej kadencji. Choć możliwość tworzenia koalicji przystających jest $\mathrm{w}$ wielu powiatach i gminach ograniczona, autor tej opinii akcentuje konieczność wypracowania przez partię polityczną całościowej strategii samorządowej:

Pewnie każda partia czy też ugrupowanie, które startuje w wyborach samorządowych, po oficjalnym ogłoszeniu wyników, przynajmniej tak się dzieje w Platformie, robi sobie taką analizę potencjału. To wtedy najlepiej usiąść już z konkretnymi osobami, radnymi poszczególnych szczebli i spojrzeć, co się wydarzyło. To jest jak gdyby, w tym momencie, normalna analiza polityczna. Co my możemy stworzyć wspólnie poprzez połączenie pewnych powiązań osobowych, koalicyjnych. Ale tutaj nie ma jakiegoś takiego warunku sine qua non, że: „jak nie zrobicie tego, to my was też nie bierzemy”, jeśli chodzi o samorząd województwa. Chcielibyśmy bardzo kontynuować to, co wspólnie robimy, na następną kadencję i dlatego na pewno priorytetem będzie koalicja samorządu województwa, a dopiero później, jeżeli się uda dogadać. Te osoby, które decydują o koalicji samorządu województwa, również decydują o koalicjach w powiatach. Myślę, że to jest do zrobienia. Tu nie ma takiej zależności zero-jedynkowej.

Po zarysowaniu tych bardziej ogólnych ram i trendu w kierunku wypracowania przez partie polityczne strategii wielopoziomowych warto zwrócić uwagę na zmiany zachodzące w czasie. Stabilizacja polityczna po 2007 roku na poziomie centrum, a także województw sprzyjała dostrzeganiu tego typu powiązań przez przedstawicieli elit regionalnych ${ }^{11}$. We wcześniejszym okresie postrzegano możliwość prowadzenia polityki uwzględniającej uwarunkowania systemu wielopoziomowego jako stosunkowo ograniczoną. Obrazuje to wypowiedź marszałka z SLD pierwszej kadencji, który zaprzeczał podejmowaniu działań zmierzających do tworzenia koalicji przystających na „szczeblu” powiatu, jak również próbie wypracowania jakiejś całościowej strategii:

My nic nie mówiliśmy o powiatach [...]. Tak naprawdę to formalnie od 1 stycznia $99 \mathrm{r}$. samorząady [...] zaczęły pomału [funkcjonować - T.M.]. Nie, na pewno nie rozmawialiśmy o pakiecie [dla kilku powiatów — T.M.]. Ja nie uczestniczyłem w tych negocjacjach jako kandydat.

Natomiast dla przedstawiciela prawicy (AWS) pierwszym skojarzeniem przy rozważaniu możliwości stworzenia koalicji przystających na niższych szczeblach był problem spójności koalicji regionalnej. Wewnętrzne konflikty AWS-UW utrudniały realizowanie tego typu projektów. Marszałek ten dopiero jako drugi czynnik powstrzymujący realizację tego typu strategii wymienił problem braku wystarczająco silnych struktur partii

11 Warto między innymi zauważyć szeroko zakrojoną tendencję do tworzenia w regionach koalicji odtwarzających koalicję rządową PO-PSL - T. Majcherkiewicz, Wzory tworzenia wojewódzkich koalicji samorządowych a skład polityczny zarządów województw w latach 1998-2014, „Studia Polityczne” 42, 2016, nr 2, s. 113-144. 
ogólnokrajowych w samorządach. Dodatkowo sformowanie „jednopartyjnych” zarządów AWS-owskich w trzech województwach, przy słabości UW na pewnych obszarach, nie sprzyjało myśleniu i wypracowaniu wielopoziomowych strategii koalicyjnych. Wynik wyborczy umożliwiający AWS samodzielne rządzenie w czterech województwach nie skłaniał przedstawicieli prawicy do odtwarzania koalicji rządowej (województwo pomorskie było wyjątkiem). Jednak warto dostrzec przeciwną tendencję w późniejszych kadencjach - w okresie koalicji rządowej PO-PSL, kiedy tworzone były w województwach koalicje przystające, nawet w przypadkach, gdy jedno z tych ugrupowań mogło rządzić samodzielnie. Powstawanie tych koalicji nadwyżkowych można interpretować jako zmianę sposobu myślenia w kierunku tworzenia strategii wielopoziomowych.

Wypowiedzi innych marszałków rządzących w dwóch pierwszych kadencjach, zarówno z prawicy, jak i lewicy, sugerują raczej, że byli oni przeciwnikami tworzenia koalicji przystających w samorządach, głównie ze względów doktrynalnych. W przypadku pierwszej kadencji od tego ogólnego wzorca opinii polityków regionalnych odróżniali się ludowcy, już wtedy dostrzegający ten rodzaj wielopoziomowości i podejmujący działania zmierzające do tworzenia „koalicji wielopoziomowych”, także poprzez tworzenie w powiatach koalicji przystających do „szczebla” wojewódzkiego:

A ponadto będziemy naszych kolegów: radnych w powiatach, jedną i drugą stronę [PSL i SLD - T.M.] przekonywać do tego, żeby koalicje na poziomie powiatowym były odbiciem koalicji na szczeblu województwa. To się nam w dużej mierze udało, przy czym już te niuanse kadrowe dogadywali na poziomie powiatowym, bo ludzie są mądrzy.

Pewne podobieństwo do wypowiedzi polityków PSL widoczne jest w opiniach marszałków PO, kierujących województwami po 2010 roku $^{12}$. Sugeruje to, że z pewnymi opóźnieniami również ta partia zaczęła wypracowywać strategie wielopoziomowe. Przykładem obrazującym ten typ myślenia jest między innymi zamieszczony na początku tego podrozdziału drugi cytat (mówiący o przygotowywaniu przez każdą partię analizy swojego potencjału), podobnie jak strategie wielopoziomowe wypracowywane w województwie śląskim. Wypowiedź ta jest interesująca, gdyż wynika z niej, że dostrzegane są nie tylko interesy lokalne, ale także ich różnorodność. W związku ze słabością PSL na tych terenach tworzenie koalicji wymagało poszerzenia jej o trzeciego partnera, a wyboru należało dokonać między dwoma potencjalnymi koalicjantami: SLD lub RAŚ. W odniesieniu do kwestii, które z tych ugrupowań należy wybrać, odmienne poglądy i interesy miały głównie miasta na prawach powiatów w różnych częściach województwa:

${ }^{12}$ Ewolucja w myśleniu polityków PO w kierunku strategii wielopoziomowych będzie szczególnie wyraźna, gdy się ją porówna z zamieszczoną poniżej opinią polityka tej partii w okresie jej hegemonii na poziomie centralnym i regionalnym. Marszałek ten sugerował powstanie modelu hierarchicznego, z ogromnym, prawie nieograniczonym wpływem centrum, czemu równocześnie towarzyszył brak wpływu „szczebla” lokalnego: „Szczebel lokalny nie miał żadnego wpływu, ten niższy. Szczebel centralny miałby wpływ stuprocentowy, gdyby tylko chciał, ale nie chciał. Władze centralne Platformy Obywatelskiej stanęły wówczas tak po prostu trochę z boku, po prostu nie angażowały się w to, dały tutaj wolną rękę. Ale wystarczyłby SMS od Donalda Tuska albo od asystenta Donalda Tuska. Wystarczyłby SMS i nie byłoby koalicji [...] albo nie było czegoś takiego". Taką interpretację wzmacnia też słownictwo: samorząd lokalny określony został jako niższy „szczebel”. 
Oczywiście, że oddziaływanie interesów lokalnych ma wpływ na kształt koalicji. Powiem tak: ci, co mają RAŚ w opozycji u siebie, mówią, że RAŚ-u nie chcą, ci co mają SLD - odwrotnie [...] i mamy taki podział: Zagłębie [...] [szczegóły dotyczące poszczególnych miast powiatowych - T.M.]. W Z. [nazwa miasta - T.M.] takie głosy były, że nie chcą SLD. Ponieważ to SLD jest głównym naszym przeciwnikiem od lat. To SLD z nami konkuruje, z nami wygrywa. [...] Natomiast, wracając do tych dołów, tam gdzieś okolice R. [nazwa miasta - T.M.], z kolei tam RAŚ jest konkurentem. To, co podejmujemy, jest wypadkową tych różnych wpływów.

Cytat ten sugeruje, że nie tylko politycy regionalni są świadomi funkcjonowania w systemie wielopoziomowym, ale również samorządowcy na poziomie dużych miast.

Na koniec warto przywołać jeszcze jedną opinię o wzorach tworzenia koalicji powiatowych po 2010 roku. W opinii tego respondenta miały one dodatkową cechę - przybrały formę tak zwanych koalicji wykluczających:

Ta presja „NIE dla PiS-u” schodziła nawet do powiatów. Byli tacy pełnomocnicy - przyjeżdżało SLD, Platforma, PSL i pilnowali, żeby nie powstała [taka koalicja - T.M.].

\section{Przejrzystość podziałów politycznych i zwolennicy upolitycznienia samorządu}

W opinii wielu marszałków prowadzenie polityki koalicyjnej, uwzględniającej uwarunkowania systemu wielopoziomowego, było ściśle powiązane z pytaniem o rolę partii w samorządzie lokalnym. Część marszałków uważała, że zwiększenie udziału partii ogólnokrajowych będzie korzystne dla samorządów.

Przy opisywaniu tej kwestii marszałkowie odwoływali się przede wszystkim do woli wyborców. Podkreślali, że obywatele potrzebują prostego, czytelnego przekazu, co wymaga zachowania spójności programowej. Wyrażać się to powinno między innymi w kształcie zawieranych w terenie koalicji, uwzględniających ogólnokrajowy podział na rząd i opozycję. Innymi słowy - unikać należy tworzenia koalicji krzyżujących.

Inni marszałkowie byli nawet bardziej radykalni i uważali, że brak partii jest grą nieuczciwą wobec wyborców:

Takie rzeczy są możliwe wtedy, kiedy partie w ogóle znikają. I mamy do czynienia z osobowościami. Jakieś dwie osobowości ze sobą się dogadują, to wtedy ludzie są w stanie to zrozumieć. Natomiast w przeciwnym razie wydaje mi się, że to absolutnie sztuczne, to jest po prostu robienie „oka” do wyborców, na zasadzie, że to wszystko jest dosyć umowne, że właściwie się niczym nie różnimy. To nie jest uczciwe w stosunku do wyborców.

Jednak inni zwolennicy upartyjnienia samorządu podkreślali, że także na „szczeblu” lokalnym, szczególnie w dużych miastach, działają te same mechanizmy partyjne, co w ogólnokrajowych partiach politycznych, tylko są one ukryte. Wprowadzenie partii ogólnokrajowych spowodowałoby, że również w przypadku tych wyborów polityka byłaby bardziej przejrzysta i spójna:

Ukryte upartyjnienie albo partie lokalne, które dokładnie powtarzają te same warianty, jak partie centralne, z tym że mają tylko charakter lokalny, i to się nazywa partia Iksińskiego, Kowalskiego, Malinowskiego, Stowarzyszenie Miłośników... i tak dalej. 
Gdynia jest klasycznym przykładem, gdzie rządzi prezydent, który oczywiście rządzi miastem i ma swoją partię. Partia ta ma dokładne mechanizmy polityczne, z obsadzeniem stanowisk, z dyscypliną partyjną, ze wszystkim. To jest takie sztuczne odejście od upartyjnienia. [...] Powiedziałbym tak: nie ma czegoś takiego jak samorządowiec, jest polityk. Polityk lokalny, polityk regionalny, polityk narodowy. Polityk, który zachowuje się politycznie; tworzy struktury polityczne, które w danym momencie są dla niego korzystne. Wykorzystuje istniejące struktury polityczne albo tworzy własne. Natomiast to jest dokładnie robota polityczna i dlatego też, jak mieliśmy do czynienia na początku z samorządami, to przecież początek był absolutnie polityczny.

Z drugiej strony liczna była też grupa przeciwników upartyjnienia, choć do pewnego stopnia „W odwrocie” (przeważają wśród nich marszałkowie pierwszej i drugiej kadencji). Upartyjnienie według tych osób kojarzone było z próbą centralizacji i podporządkowania władzom centralnym:

A dla mnie silny samorząd i zdywersyfikowany politycznie to jest coś, co czyni to państwo bardziej wstrząsoodpornym i powinno być jako takie pielęgnowane. Widzę w tym zagrożenia, bo po 2007 roku poszła nieprawdopodobnie silna presja i to mówię z całą odpowiedzialnością - to się zaczęło od objęcia władzy przez Donalda Tuska, że poszła nieprawdopodobnie silna presja na upartyjnienie samorządów i na taki jasny podział nasz - nie nasz. To jest ze szkodą dla państwa jako takiego.

Również druga, bardzo krytyczna wypowiedź sugeruje, że próba upartyjnienia to w rzeczywistości wyraz dążenia do podporządkowania sobie samorządów przez centrum. Jedyną różnicą między cytatami jest odpowiedź na pytanie, które partie ogólnokrajowe prowadziły taką politykę. W poniższej opinii, podobnie jak u wielu innych respondentów, tendencja ta występuje we wszystkich partiach ogólnokrajowych i można ją uznać za przejaw obowiązującej kultury politycznej:

To jest chore, jak chory jest cały system. Nie wiem, jak to nazwać: decentralizacją czy centralizacją. [...] Bardzo mocno w ostatnich dwóch, nawet trzech kadencjach samorządowych doszło do upartyjnienia samorządów. To upartyjnienie, zamiast się gdzieś tam kurczyć, ono się jeszcze bardziej rozszerza, schodząc na dół. Najlepiej, by w tej chwili upartyjnili każdą gminę, to jest chore [...].

Jednym z tych elementów jest to, że się próbuje przekładać ten układ koalicyjny rządowy na ten szczebel, który jest najbliżej rządu, czyli ten samorządowy [...].

Każda z tych partii jakby próbuje robić ten odcisk. A to środowisko samorządowe nie broni się przeciw temu. Dlaczego? Dlatego, że nie ma odciętej pępowiny pomiędzy tym, co jest rządowe a co jest na poziomie samorządowym. Czyli ta niezależność zadaniowa, finansowa samorządów jest w dalszym ciągu niewielka.

Wypowiedź ta wskazuje, że samo upartyjnienie nie jest złe, ale staje się ono problemem w związku z ograniczonym zakresem decentralizacji. Warto zauważyć, że według perspektywy MLG tradycyjny model państwa $z$ dominującym centrum zastępowany jest przez system, gdzie władza jest bardziej rozproszona. W opracowaniach poświęconych relacjom centrum-region w krajach Europy Zachodniej zwraca się uwagę na ich wzajemne zależności. Natomiast powyższy opis polityki prowadzonej przez centrale partii politycznych w stosunku do samorządów sugeruje relację hierarchiczną — jednostronnego podporządkowania. 


\section{Zakończenie}

Wywiady z marszałkami województw, dotyczące relacji między poziomem regionalnym a lokalnym, wskazują, że również w polskich samorządach możemy mówić o powstaniu systemu wielopoziomowego, do którego partie polityczne coraz skuteczniej dopasowują swoje strategie. $\mathrm{W}$ literaturze przedmiotu, jak również $\mathrm{w}$ wypowiedziach samych marszałków, więcej opisów poświęconych było relacji między „szczeblem” centralnym i regionalnym. Równocześnie relacje te uznawane były za ważniejsze. Jednak w badanym okresie, kiedy samorządy regionalne decydowały o dostępie do funduszy europejskich, dostrzec trzeba wagę powiązań także między poziomem regionalnym i lokalnym.

W relacjach miasta-województwo trzy kwestie wydają się szczególnie interesujące. Po pierwsze, opisane w tym artykule oddziaływanie zmian politycznych w radzie miasta Olsztyna na zarząd województwa ukazało, że analizę należy rozszerzyć na kolejne poziomy, a także uwzględnić rolę centrum. Zmiana w samorządzie wojewódzkim wywołała zmiany kadrowe w kierownictwie urzędu wojewódzkiego. Podobnie protesty samorządowców w określonych subregionach wobec ograniczeń w dostępie do funduszy europejskich należałoby interpretować nie jako relację dwupoziomową, ale wielopoziomową, ukazującą też znaczenie poziomu europejskiego.

Po drugie, pomimo wprowadzenia bezpośrednich wyborów na prezydentów miast i dystansowania się wielu lokalnych przywódców od polityki krajowej respondenci wskazywali, że w wielu przypadkach dochodzi do wymiany zasobów i wzajemnej współpracy.

Po trzecie, opis relacji powiat-województwo wskazuje na ewolucję postrzegania przez polityków tego typu powiązań. W początkowym okresie dostrzec można próby tworzenia przez polityków PSL koalicji przystających, a w przypadku przedstawicieli innych ugrupowań podkreślana jest raczej odrębność polityki powiatowej. Natomiast marszałkowie ostatnich kadencji wskazują, że partie podejmują próby wypracowania wielopoziomowych strategii umożliwiających zwiększenie ich wpływów. Rozważania dotyczące budowania koalicji powiatowych prowokowały wielu marszałków do postawienia pytania o rolę ogólnokrajowych partii politycznych w samorządzie; zarówno opcja większego upartyjnienia, jak i jemu przeciwna miały wielu zwolenników. Jednak obie grupy łączy stosunek do demokracji: politycy będący orędownikami większego upartyjnienia podkreślali, że przyczyni się to do większej klarowności decyzji politycznych, będą one bardziej zrozumiałe dla wyborców. Niektórzy używali nawet radykalnych zwrotów mówiących, że wymaga tego uczciwość wobec wyborców. Natomiast dla zwolenników drugiej opcji odrzucenie upartyjnienia to właśnie gwarancja zachowania niezależności, co w ich opinii konieczne było dla rozwoju lokalnej demokracji.

\section{Bibliografia}

Bober J. et al., Narastające dysfunkcje, zasadnicze dylematy, konieczne działania. Raport o stanie samorzadności terytorialnej w Polsce, Uniwersytet Ekonomiczny - Małopolska Szkoła Administracji Publicznej, Kraków 2013. 
Borchert J., Stolz K., Introduction: Political careers in multi-level systems, „Regional \& Federal Studies” 21, 2011, $\mathrm{nr} 2$.

Botella J. et al., A new political elite in Western Europe? The political careers of regional prime ministers in newly decentralised countries, „French Politics” 8, 2010, nr 1.

Deschouwer K., Formation and congruence in a multi-layered setting: Belgium 1995-2008, „Regional \& Federal Studies" 19, 2009, nr 1.

Deschouwer K., Multilevel systems and political careers: the pleasures of getting lost, ECPR Joint Sessions of Workshops, Grenoble, 6-11 kwietnia 2001, https://ecpr.eu/Filestore/PaperProposal/a06d1462-2ca449e9-8f93-dc5198ba515e.pdf (dostęp: 20.03.2020).

Detterbeck K., Renzsch W., Multi-Level electoral competition: The German case, „European Urban and Regional Studies" 10, 2003, nr 3.

Gajowniczek T., Bastion lewicy zdobyty. Wybory samorządowe w województwie warmińsko-mazurskim, [w:] R. Alberski, M. Cichosz, Ł. Tomczak, Wybory do sejmików województw w 2006 roku, Wydawnictwo Marina, Wrocław 2010.

Jeffery C., Multi-Level Party Competition in Federal and Regional States, [w:] Handbook on Multi-Level Governance, red. H. Enderlein, S. Wälti, M. Zürn, Edward Elgar Publishing Limited, Cheltenham 2011.

Linhart E., Coalition building on the federal and on the länder level in Germany, IPSA World Congress of Political Science, Poznań, 23-28 lipca 2016.

Majcherkiewicz T., Koalicje regionalne w perspektywie rządzenia wielopoziomowego, „Studia Polityczne” 4, 2017, $\mathrm{nr} 45$.

Majcherkiewicz T., Marszałkowie województw jako politycy regionalni i reprezentanci społeczności regionalnych, „Studia Humanistyczne AGH” 3, 2017, nr 16.

Majcherkiewicz T., Wzory tworzenia wojewódzkich koalicji samorządowych a skład polityczny zarządów województw w latach 1998-2014, „Studia Polityczne” 42, 2016, nr 2.

Pietkun P., Sejmik wzięty, „Gazeta w Elblągu” 9 października 1999.

Sepioł J., Pejzaż dziesięciolecia, „Gazeta Wyborcza” (dodatek krakowski), 19 stycznia 2009.

Ştefuriuc I., Government Formation in Multi-Level Settings: Party Strategy and Institutional Constraints, Palgrave Macmillan, Basingstoke 2013.

\section{Development of a multilevel system in Poland demonstrated by the example of relations between regional and local self-government}

Keywords: multilevel system, heads of regional boards, coalitions, local and regional self-government

\section{Summary}

The article investigates the formation of a multilevel system in Poland as reported by heads of regional boards governing in the period 1998-2014. Assuming that a modern democratic state (a standard of which is the existence of regional self-government) requires some cooperation among levels that between the central and regional is traditionally recognised as crucial. Nevertheless, it is worth investigating whether a partnership develops between regional and local levels, and what is its form. According to the heads of regional boards, two forms of coordination are critical: first, the formation of a congruent coalition at district level to that in a particular region, and second, close cooperation with cities which had the status of regional capitals. 